\title{
Cool Carriers
}

The day Saléninvest's bankruptcy was announced, it was doom and gloom for many at the office on Norrlandsgatan, Stockholm 1 . Many of the former employees at Saléninvest barely knew what they were going to do, but the management of the reefer division Salen Reefer Services (SRS) were completely prepared. Mats Ruhne and his closest executives, also known as the Five, had feared that the end was near for Saléninvest and had made plans to quickly revive the reefer division, in case of a bankruptcy. In November 1984, a company was created called Salén Supporters. Officially, the investor was Gyllenhammar and Partners, but Stenbeck and Sven and Christer Salén were also involved. There was a feeling that the reefer division was the genuine Saléns, that it was world-leading, and that it could not be allowed to fall just because other divisions had failed.

When the bankruptcy was a fact, the backup plan was activated and a new reefer operation was in place the day after the bankruptcy. A person who was there from the start in the almost identically-named new company, SRs Reefer, says that "we found it hard to keep a straight face among all the sadness. We felt an incredible joy to work. We got up and rushed to work while everyone else at the defunct Saléninvest were staring into the walls". Everyone in the reefer section knew what had to be done. When a shipping company goes bankrupt, there are always gold-diggers appearing to see how they can profit from the mess. SRS Reefer needed to win the race against these gold-diggers. In some way, perhaps SRS Reefer was lucky regarding the timing of the bankruptcy. While many reefer companies checked out in order to celebrate Christmas and New Year, at SRs Reefer it was full steam ahead.

1 This part is based on annual reports of Cool Carriers and its owners, the annual review of Cool Carriers called Cool Facts, newspaper clippings from Swedish and international newspapers, articles in Svensk Sjöfarts Tidning, archival material from Mats Ruhne's private archive, as well as a large number of interviews with management and employees of Cool Carriers as well as their owners. We have also made use of already published literature about the post-Salénbankruptcy businesses such as Sjöberg 2007, Sjögren, H. 1997. Spelet i Saléninvest, Stockholm: Ekerlid, Fagerfäll, R. 1999, Företagsledarnas århundrade. D. 3, 1967-20oo: från Werthéns förvärvsstrategi till Barneviks globala nätverk, Stockholm: Norstedts., Lennerfors, T.T. 2009, Stockholmsrederierna - Ägandet och nätverkens betydelse för tanksjöfartens utveckling $i$ Stockholm 1980-200o, Göteborg: BAS \& Breakwater Publishing. Müller, L., Hallén, P. and Lennerfors, T.T. 2016. Handel och sjöfart, in Ekström, S., Müller, L., and Nilson, T. 2016. Sjövägen till Sverige: Från 150o-talet till våra dagar, Malmö: Universus Academic Press, pp. 69-120. 
A "command centre" was built up in Saléninvest's offices. The SRS fleet list was posted on the wall next to a list of SRs' customers. Half of the employees started phoning around to the shipowners to convince them to reemploy the ships within SRS Reefer. Some owners, however, were sitting on contracts with good charter rates, and these were renegotiated after the bankruptcy. Many shipowners were involuntary, for example banks and the Swedish state, and those often agreed to let SRs Reefer commercially operate their ships. The second half of the employees phoned around to customers and assured them that everything was business as usual. One might wonder how many customers actually realized that Saléninvest had gone.

While the Swedes were preparing for Santa Claus and the Swedish tradition of watching Donald Duck on Christmas Eve, the command centre was imbued with cigarette smoke and the smell of strong, very strong coffee. Through the door of the office and into the room stepped the CEO of SRS Reefer, Mats Ruhne, who had jogged along with his dog to the office. It was freezing cold and both Ruhne and the dog were covered with ice. But the staff remember that Mats Ruhne infused courage and work enthusiasm into the group. They shared this task, there was solidarity, they sacrificed their leisure and their families in order to save the business, and their jobs.

SRS Reefer, soon renamed Cool Carriers, was devoted to operating but not owning ships. In the Swedish Shipping Gazette in January 1985, Christer Salén explained that the new reefer operation "shall own vessels only exceptionally and this means that we will operate with a much lower risk profile. It will not have the same exposure [to risk] as in the old company [Saléninvest]"2. The company tried to position itself through discourse as more of a "software" company than its predecessor. More brokering, more an organizer of pools, operating vessels for others, using some chartered-in tonnage. It was disclosed that the company would also focus on modern ships with large hatch openings (i.e. the Winter and Spring vessels), the right dimensions of the holds, and right angles, all to improve the efficiency of loading and unloading.

Behind the scenes, the Five went around to banks and made deals in order to secure tonnage for their operation, because they knew that despite the discursive positioning as a software company, without control of tonnage the company was nothing. The ownership structure of the ships was very complicated, and it has been repeatedly stated that very few knew how the whole set-up was organized. However, it is clear that the owners of sRs Reefer, in other words, those who had provided capital for the business as well as the Five, were also trying to get ownership of the hardware - the ships. It was also

2 "Saléns seglar vidare. Nytt bolag håller kylsjöfarten igång”. Svensk Sjöfarts Tidning 1985/1-2, p. 2. 


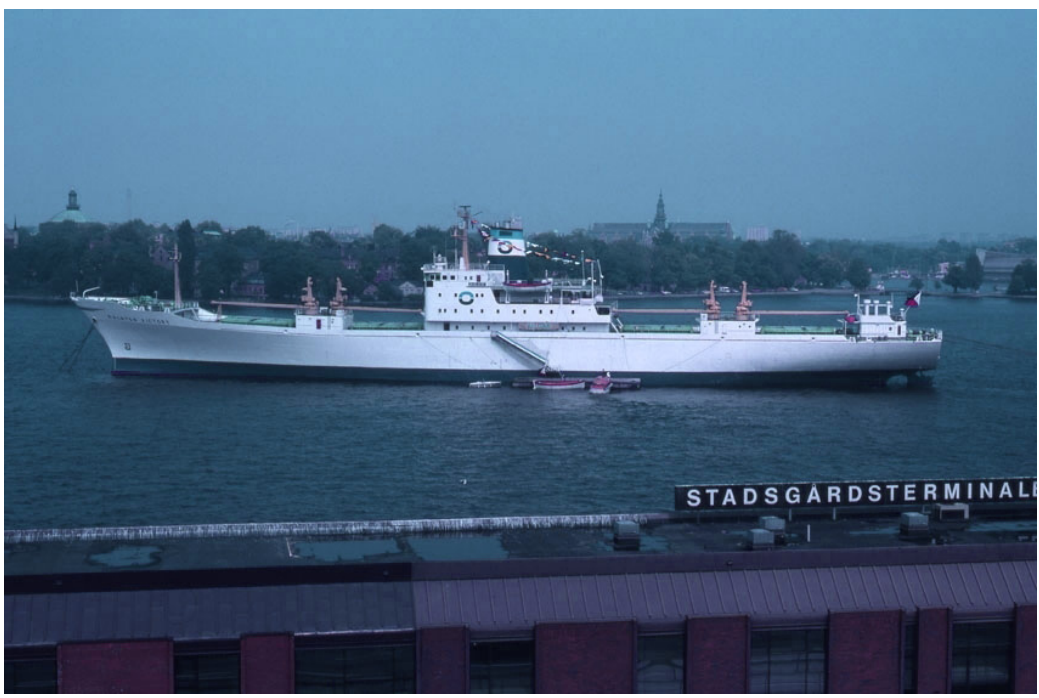

FIGURE 8 Cool Carriers managed to secure the operation of most of Salén's reefer tonnage following the bankruptcy. Pictured is the San Blas from 1967, renamed the Malayan Victory, in Stockholm 1986 PHOTO: ÖSTRING, BILL/ SJÖHISTORISKA MUSEET

shortly after the bankruptcy that personnel at Cool Carriers started to understand who was actually owning the company. An employee explains:

After the urgent time was over, after a month or so, it started to become clear to us that the Five had ownership in the company. The whole teamspirit was gone, a cold wind swept through the company. We were degraded to just workers. It was the Five and there was us. They lost the trust of the personnel.

This was the start of an increasingly collective collegiality amongst the employees, and against some of the owners. These employees started to perceive the owners as antagonists, rather than on their side. This subjective perception would strongly influence the history of Cool Carriers.

Initially the ships were operated under what was called a best effort system, i.e., that the owners of a ship got what the ship had earned minus an operations fee which SRs Reefer took. However, this could lead to one ship getting really good trades and earning a lot of money, while another ship received poor trades and did not earn anything at all. Furthermore, the best effort system could lead to owners suspecting that other owners were favoured. This could be avoided by creating a pool where all ships shared the revenue from the en- 
Seasonal Fruits Division: citrus, apples, pears and grapes to the North European continent and North America

$\begin{array}{lll}\begin{array}{l}\text { Trans Pacific Division: A } \\ \text { service with five Spring } \\ \text { vessels between Long }\end{array} & \begin{array}{l}\text { Division Tropical } \\ \text { Fruits: Bananas }\end{array} & \begin{array}{l}\text { Worldwide Tramping Division: } \\ \text { frozen fish and similar to the Far }\end{array} \\ \begin{array}{l}\text { Beach and Japan. Trays } \\ \text { of fruits and vegetables, }\end{array} & & \begin{array}{l}\text { East, chilled and frozen meat } \\ \text { from NZ, fruit from Chile, cars }\end{array} \\ \begin{array}{l}\text { refrigerated and dry cargo } \\ \text { containers, each week }\end{array} & \text { from Japan, apples from the } \\ \text { (liner type) } & \text { United States. Transport to the } \\ & \text { Middle East. Also a line from }\end{array}$

GRAPH 13 Cool Carriers' organization

tire pool ${ }^{3}$. The pool that materialized was called Leonina. The name was chosen since Leonina was considered to represent the lion's mother who protects her little lion cubs - in other words, the big, strong, experienced sRs Reefer who protected the ship-owners. This was how the management of Cool Carriers perceived of the company and how they discursively constructed its purpose. That Leonina later was discovered to be an old Biblical myth - about a lion who hunts together with an antelope - led to significant confusion about what Leonina really meant. Furthermore, in business language, Leonina could even be seen to refer to leonine clauses in contracts - clauses that are heavily biased.

Somewhat into the year of 1985, SRS Reefer had gained control over some 6o-70 vessels. A few months later, in April, it moved out to new offices outside the city at Danderyd. The budgeted revenues were 2 billion and a profit of 49 million SEK. The organization was identical to that in Saléninvest, depicted in Graph 13 .

Cool Carriers was thriving, with new contracts, such as transporting ten large shiploads of octopus to Japan in the first half of 1986, and a large banana contract from Colombia, primarily, and Ecuador to the United States in 1986. The banana contract concerned 17 million banana boxes employing 6-7 vessels. The fruit was delivered by Uniban in Colombia, shipped to Galveston, Tampa and Newark, received by Turbana (Uniban's sales company). The financial outcome of the first year of operations was a profit of 5 om SEK.

3 "All permanent ships employed in the Leonina System (i.e. not the pool's own short term tonnage) share the System's net result on the basis of (a) the ships' cubic capacity (b) the number of days in the System and (c) a factor (trade factor) which reflects the ships' suitability for the various trades which are served by the System. While there is a great number of inputs which go into the mathematical determination of these factors, the main ones reflect the ships' suitability for pallet cargoes, fuel consumption, and cargo handling facilities. [...] The trade factors are checked yearly to reflect changes in market conditions, bunker prices and also the ships' actual performance". Cool Carriers Information Memorandum December 1986, p. 4. Mats Ruhne's private archive. 
Given the successful development of Cool Carriers the upper management led by Mats Ruhne started to subjectively perceive themselves increasingly as entrepreneurs, although their ownership in the company was limited. A classical conflict between owners and managers ensued, where the principal struggle was personified as Mats Ruhne vs. Jan Stenbeck. There are a number of stories related to this struggle and it is unlikely that it will ever be established what really happened. The conflict was aggravated by all the assets that were outside Cool Carriers, namely the ships. The owners of Cool Carriers were trying to get control of the ships that were owned by banks and managed to do so. Who was invited to each deal and who was not became a core issue of the conflict, as well as who the banks think they sold the ships to - was it to a daughter company to Cool Carriers or to the owners as private persons? Another conflict concerned what company should be chosen to be an insurance provider to the new cargo insurance that Cool Carriers offered to its pool members. When the managers decided to not use Stenbeck's insurance company, this was not received favourably. Stenbeck called in auditors and claimed that Ruhne had embezzled money from the company. When the Five returned from negotiations to buy the six Winter vessels from the Swedish state shipping company Zenit ${ }^{4}$, there was a security guard with a guard dog in front of the main door, hindering them from entering.

Perfresh

The Five decided to start up something of their own ${ }^{5}$. They bought into a stock-listed company named Percal and renamed it Perfresh. Perfresh filled four main functions. First, to be a base so that they could continue working with existing customer contacts and forge new ones. Second, Perfresh intended to own ships. Right from the start, they had brought with them five vessels from Cool Carriers that were owned by the banks. The Five managed chartering and operation of the vessels. Third, Perfresh developed an import and distribution business in the fruit and vegetable trade. Previously Cool Carriers had been part owner of the Dutch fruit and vegetable importer Jan van den Brink. This company had successfully managed to build a business around small shops that sold vegetables throughout Holland. Perfresh and Jan van den Brink tried to launch this concept in Denmark, but with little success. Fourthly,

4 Zenit is described in Lennerfors, T.T. 2014. An involuntary ship owner - the background and effects of Swedish state involvement in shipping during the 1970's and 1980's, International Journal of Maritime History, 26: 702-719.

5 Part of this episode is described in "Nya kylrederiet Perfresh förvärvar första fartyget". Svensk Sjöfarts Tidning 1986/49, p. 2. 
the Five thought that the time was right to build new reefers. Perfresh developed a ship based on the knowledge accumulated within Salén and Cool Carriers and Per-Olof Oweson went to the Gdansk shipyard in Poland to negotiate. The yard initially agreed to build some ships at what looked to be a very low price. Subsequently, the yard was forced to change the deal and at this point the narrative diverges as to exactly what happened. Oweson's perspective is based upon that Perfresh had cancelled the deal while the remaining Four claim that the deal was still under negotiation. However, the broker - Christian Larsson - considered the revised higher price from the yard to still represent good value and tried to recruit investors and one of those was Oweson, who subsequently left Perfresh. The Five had become Four.

The legal dispute between Stenbeck and Ruhne continued and these highlevel conflicts affected Cool Carriers which became somewhat paralyzed. However, because of the subjectively perceived antagonism between the upper managers and the organization at Cool Carriers, the lower echelons of the organization decided to collaborate with owners not directly involved in the conflict to find a solution to the problem. They approached Bilspedition as a potential buyer of Cool Carriers, in order to find a solution to the ownership situation.

After some twists and turns, the whole package, Perfresh and Cool Carriers, was sold to Bilspedition.

\section{Holy House}

After the settlement with Bilspedition, Mats Ruhne controlled a number of vessels including four of the Snow ships. These ships became the foundation for Mats Ruhne's Holy House Shippinga, which still exists today (2018). The purpose of Holy House Shipping was to be a shipowner and to timecharter ships to operators. Cool Carriers chartered a few ships but some people at Cool Carriers still mistrusted Ruhne, so Holy House decided to approach the customers of Cool Carriers - banana companies. From 1990 to 1995, Holy House chartered their ships to Chiquita and this resulted in a confict that is notable. When the EU banana regulations were altered, the reefer market was negatively affected, and Chiquita broke the contract with Holy House two years before the end date of the timecharter. They claimed that the Snow vessels did not conform to the deck height specification. Holy House started arbitration against Chiquita, and finally won a 10m USD claim against GWF, Chiquita's shipping arm, in 1997. After all, Chiquita had signed the contract and had accepted the Snow's configuration. When the contract with Chiquita was lost, the ships were timechartered and went in traffic to Capespan (South Africa) until 2005. 
During the second half of the 1990s, Holy House expanded their fleet with second hand tonnage. These vessels were of varying age, in fact most were quite old, but the main commonality of these purchases was that they represented good value for moneyb. By 2001, the Holy House fleet consisted of 17 ships. The fleet remained stable, but after the crisis of 2008/2009 Holy House scaled down their fleet to five ships. In 2013, they bought Hansa Bremen and Hansa Lübeck and employed them in NYK Cool but later transferred them to Seatrade's pool. In 2015, they had seven reefers in their fleet, and in 2017, they had four. The strategy of Holy House over the years has been to own a fleet of well-maintained large ships, that despite their age could compete for the same trades as the major independent operators.

Note: a Written on the base of publicly available material in TradeWinds, the Holy House webpage as well as interviews with Mats Ruhne and Anna Börjesson Ruhne; b In 1996, Laponian, built in 1992, was acquired for 20-21 mUSD. Two years later Kea (built in 1982) and Kyma (1972) were bought for 9m and 4.5m, and later Kudu (1984) for 3.2m. In 2001, Holy House also purchased three 1970s-built reefers, the Selma (1979), Cherry and Morillo (both 1971) at a low price of $\$ 3.5 \mathrm{~m}$ in June. In September 2001, they bought the Pacific Star, Atlantic Star, Baltic Star and Tasman Star (all 1983) en bloc for a reported \$9.5m from Tokumaru Kaiun.

\section{Caesar Reefers}

Caesar Reefers came about as a result of Perfresh not going through with the constructions of the vessels in Gdansk as outlined previously. This was one of the most profitable deals during the last 30 years in the reefer market. Many other speculative ship-owners, with no interest in own commercial operations, invested during this period. This story exemplifies the realities of ship-owning and reefer investment.

The Swedish ship-owner and businessman Mats Arnhög was a leading investor in the consortia that took over the deal. The ships were going to be built at the Lenin shipyard at Gdansk in Poland and both Arnhög and the broker Christian Larsson had a past relationship with the shipyard. When Mats was working for the oil trader STC, STC had placed an order of six medium-sized tankers (40 ooo dwt $\mathrm{t}^{\mathrm{b}}$ ) at that very shipyard in 1979 brokered by Christian Larsson. This was not just any Polish shipyard, nor any time period, seen in hindsight. It was during the building of these very tankers that Lech Wałęsa founded the Solidarity trade union movement on 14 August 1980 at the shipyard.

Christian Larsson knew that Arnhög was an interested investor within the shipping segment, and therefore reached out to him. At first, Arnhög 
was not interested in the deal, but the Poles were persistant and after eight days of negotations in Stockholm, a deal was signed for six ships but with the right to cancel four of them. At first, the ownership consortia never intended to be the owners of the ships, but rather thought of the newbuilding contracts as a form of speculation. When it was clear that the market was improving, as it did during the end of the 1980s, gradually the ownership consortium became convinced that they wanted the ships to be delivered to leverage their speculation.

To handle technical management of the ships Johan Reksten was contacted. He had relationships with the same shipyard since the 1970s. Johan Reksten is the son of Hilmar Reksten, who was not only a shipowner but also a Norwegian hero, who had assisted the Norwegian government from London during the Second World War. Hilmar was deemed to be the richest man on the globe in 1973- but was exposed to risk since he had all his VLCC oil tankers in the spot market, and Johan was portrayed on the front page of Time as the world's richest heir. What followed was a long period of misfortunes, where the dark side of a Norwegian national hero was unmasked. After the collapse of the Reksten empire, Johan Reksten had kept a technical management organization in Bergen, which was entrusted to manage the reefers.

During the building of the ships, the Polish Department of Industry decided to dismantle the shipyard, which was a great risk to the investor consortia. Certainly, they had bank guarantees, which would theoretically allow them to get all invested money back if the ships were not delivered. But it was unclear how much these guarantees were worth. The earlier relationships that Arnhög, Larsson, and Reksten had to the shipyard were proven to be of high value. The manager of the shipyard when STC built the product tankers had now become No.2 in the Department of Industry, and a meeting was set up with him and the Minister of Industry. After the meeting, the minister was on board, convinced that the ships should be finished.

When the ownership consortium had decided to take delivery of the ships, they needed to find a customer. At first, a deal was almost struck with Chiquita, but through a broker, Dole approached Arnhög, with a better deal. The fleet of six ships were going to handle Dole's Central American exports to Europe, and the ships were timechartered to Dole for four years with an option for another two years. All of the crew was Polish, including the top tiers. The ships worked very well in the service for Dole and the timecharter rates of over 90 cents per cbf were very favourable for the shipowner. 
After the timecharters were prolonged, the investor consortia decided to sell the ships, due to two reasons: First, the market was still strong, but deteriorating. Second, the trend of containerization grew stronger. They got an offer from the Oetker group to buy the ships, including personnel, and timecharter contracts, and the deal was sealed.

Note: a This section is based on archival material in the form of drawings, contracts, for the newbuildings, as well as interviews with key actors such as Mats Arnhög, Christian Larsson, and Per-Olof Oweson. The story about the shipping investments of Mats Arnhög are described in Lennerfors, T.T. 2016. Elling Ellingsen - The Shipping Entrepreneur, Stockholm: Medströms; b Deadweight tonnage (DWT) expresses the quantity of goods a ship can carry including provisions, lubricants, and fuel.

Bilspedition as Owner: Ship Investments and the Golden gos that Never Came

To understand Bilspedition's ownership of Cool Carrier, it is necessary to give a brief orientation about what kind of company Bilspedition was ${ }^{6}$. In the early 1980s, Bilspedition was a land logistics company, basically trucking, owned by truck-owners and Saléninvest. In 1982, Martin Lundberg became CEO of Bilspedition and embarked on an expansive strategy. Lundberg has explained that Bilspedition was quite strong in the Swedish market but weak internationally and that they had to grow in order to offer a complete transport solution, to become a full transport house. Parallel with this, and perhaps even more important, was the will of the CEO to grow and leverage the company. Since organic growth was perceived as too slow, Bilspedition started to buy other companies. Scansped, Sweden's largest group in international transport and forwarding, was purchased in 1985. Later, Bilspedition bought land logistics companies in Finland, Norway, Denmark and Poland. It also expanded offshore. Most of the shipping investments were done because of the potential profits in the segments, but some synergies were also envisioned. Bilspedition expanded into bulk carriers, but for our purpose the most important deal is when they bought Cool Carriers.

Strategic change in two dimensions followed at Cool Carriers from 1987 and onwards. First, Cool Carriers revised its fleet policy. Rather than just operating tonnage that was owned by a surrounding ecosystem of ship-owners, Cool Carriers began to invest in its own newbuildings, and second-hand tonnage. Relating to our discussion about various actors in chapter 1, Cool Carriers became

6 Lennerfors 2009, pp. 115-116. Apart from interviews with Cool Carriers, this part draws on interviews with Martin Lundberg, the manager of Bilspedition, as well as Göran Bergkvist, head of ScanShip, the shipping division at Bilspedition. 
more of a ship-owner than it once was. In corporate documents, it was explained that Cool Carriers had transferred from a cautious low-risk philosophy to higher risk strategy ${ }^{7}$. The new policy was that about $40-50 \%$ of the pool should consist of long-timecharters and owned tonnage. Cool Carriers invested 65 million USD between 1987 and $1990^{8}$ and committed to long-term timecharters, amounting to $1135 \mathrm{~m} \mathrm{SEK}$ from $1990-1995^{9}$. The feeling at the time was:

The revised policy implies an altered course towards a higher risk profile, but with substantially increased profit potentials and, above all, longterm expansion and control of the core fleet. The significance of the latter aspect can hardly be overemphasized by Cool Carriers as a dominant player in a rising market ${ }^{10}$.

In this fleet renewal, the competencies of Cool Carriers, inherited from Salén, could be used. The ship types, such as the Crystal class and the Northern reefer class, were developed by Cool Carriers. Although it was framed as an ambitious $R \& D$ programme ${ }^{11}$, many internal sources have explained that these ship types were not innovative, but rather just efficient and simple specialized reefers. In a sense, the changes made were just incrementally better than the latest ship types developed at Saléns - the Spring vessels. An idea of the magnitude of the fleet renewal is to see a snapshot of delivered or to be delivered tonnage to Cool Carriers or related owners from 1989 (See Table 2).

Second, apart from expanding the fleet, Cool Carriers was embarking on a path of vertical integration - to become an integrated provider of transport. It integrated vertically regarding the maritime business. Rather than the pool being the core business of Cool Carriers, its business areas quickly expanded for example into crewing and technical management. Also, it has been explained that the CEO, Bo Natt och Dag was strongly promoting the development of the vision of the complete Cool House (Sw. Kylhuset) that aimed at expanding the business beyond sea transport. For example, terminals were added to the business. Furthermore, attempts were made to investigate whether Bilspedition's land logistics business (Autotransit) in the Netherlands could serve as a partner to Cool Carriers in order to integrate vertically to be able to deliver refriger-

\footnotetext{
$7 \quad$ Cool Facts 1989, p. 5 .

8 Cool Facts 1990, p. 5 .

9 Report to the board of directors of Cool Carriers, p. 5. Presented in March 1988 by Peter Rothschild and Mats Ruhne. Mats Ruhne's private archive.

10 Cool Facts 1989, p. 5 .

11 Cool Facts 1989, p. 5 .
} 
White Dolphin, 1988

White Manta, 1989

Hansa Bremen, 1989

Hansa Visby, 1989

White Castle, 1989

Ivory Bay, 1989

Atlantik Frigo, 1989

Amer Himalaya, 1990

Amer Fuji, 1990

Ivory Ace, 1990

Pacifik Frigo, 1990

Ivory Cape, 1990

Blue Crest, 1990

Hansa Lübeck, 1990

Hansa Stockholm, 1991

Blue Cloud, 1991

Blue Ice, 1991

Blue Sky, 1991

Crystal Prince, 1991

Crystal Pride, 1992

Crystal Primadonna, 1992

Crystal Privilege, 1992

ated goods inland in the Netherlands. The conclusion was that there were no synergies.

According to a board member of Cool Carriers, "The feeling was that Bilspedition changed very much of Cool". But what explains this strategy of growth, financial risk-taking, and vertical integration? The first explanation is the very reason for which Bilspedition bought Cool Carriers. According to Martin Lundberg, Cool Carriers was bought in order to sell it to Lauritzen in exchange for Tor Line and DFDS's land logistic business that Lauritzen owned:

We wanted to buy Tor Line and DFDs transport and spedition business, since they had entered the market as one of our competitors. That was troublesome, since they were very competitive. 
Lundberg of course knew that Lauritzen was interested in reefers, but one should also point out that Lauritzen's reefer division was at the time ailing and under revision by the consultancy company McKinsey. Lauritzen was therefore probably not very willing to invest in the reefer segment. Another reason which complicated the deal were the European authorities. Lauritzen would become too important on the reefer market if they merged with Cool Carriers. Informal negotiations with the authorities in Brussels were held, but they were lengthy, time-consuming, and did not result in the desired outcome. A third obstacle, as so often happens in mergers and acquisitions, was that the owners of Lauritzen and Bilspedition had diverging ideas about the value of the companies that were pieces in the transaction. Eventually, the deal never materialized, but it had impact on the strategy. A software company will inevitably be less valuable than a hardware company, and Bilspedition's fleet expansion policy was partly related to a wish to make Cool Carriers a more valuable object to trade with Lauritzen.

The second reason is the very business philosophy and strategy of Bilspedition. It was a company focused on high growth and it had a high risk profile. This was partly due to the agency of Martin Lundberg but also because of the context of the stock market. Bilspedition's ambitions were fuelled by cheers from many stock market analysts and investors, since increased ownership of reefer vessels could lead to higher earnings and stock price. This owner strategy strongly affected Cool Carriers. A related reason was that many Swedish ship-owners were at this time expanding and it is likely that Bilspedition got confidence from this collective expansion. A last explanation was that the business strategy of the early years of Cool Carriers was no longer seen to be viable. Martin Lundberg explains that "We had difficulties in securing the tonnage for our operations. We had to abandon the idea that we were just pool operators". When the market gets better, some owners decide to operate the ships by themselves or timecharter them out directly to some customer. This led to a contraction of Cool Carriers' pool which had to be compensated with own tonnage. In short, while the pool strategy was beneficial in a lukewarm market, in a growing market the policy had to be changed.

\section{The Winter Ships Return to Swedish Ownership}

In 1988, three Winter ships, developed by Salén in the end of the 1970s, were bought by the Swedish shipping entrepreneur Folke Patriksson and his new business partner Lennart Bylock. It was the initiating business deal in the new partnership which soon became formalized as Bylock \& Nordsjöfrakt. Folke, in his autobiography, explained that: 
"One day Lennart called from London. There he had encountered Christer Salén, which had been told that three of Salén's old, nice reefers were up for sale for a good price. Both Lennart and I thought it was an attractive project. We took the chance and together bought three of the so-called Winter vessels, Winter Water, Winter Wave, and Winter Moon. Bylock got 60 percent, Nordsjöfrakt 40. It was our first joint deal"a.

A few years later the remaining three Winter ships were bought by the newly formed Bylock \& Nordsjöfrakt (B\&N). When the ships were bought, the company had no competence in reefers, and therefore intended to function as a ship-owner, outsourcing commercial operations. Still, the reefers did something to Bylock \& Nordsjöfrakt. Nordsjöfrakt had earlier just been in the short-sea shipping segment, and the reefers took B\&N to the next level. It became an international company.

"To begin with, almost all our ships were bunched up in the North Sea and Baltic Sea, it was really just the Winter boats that were spread out across the map's vast oceans. But it was a new world that lay before us"b.

Bilspedition owned parts of Nordsjöfrakt and B\&N employed their vessels in the Cool Carriers pool. There were even plans to merge B\&N with Cool Carriers, which would make sense from Bilspedition's perspective. Bilspedition was, as we have noted, interested in making structural deals. But nothing materialized. Furthermore, Seatrade had grown to become a new major player within the reefer industry in the 199os, and $\mathrm{B} \& \mathrm{~N}$ decided to try out this pool. But for B\&N, the reefers were not the core business.

After various offers to buy the Winter vessels from Cool Carrier's new owner Höegh and one of its former owners Mats Ruhne, in 1997, Svenska Orient Linien $\mathrm{AB}$, owned by $\mathrm{B} \& N$ underwent an IPO and the six Winter vessels were part of that IPO. The reefer market was good in 1997, so the Winter vessels were a way to make the offer more enticing. Later, the ships were sold by SOL at a low price.

Notes: a Patriksson, F. narrated for Ulla Linton, 2012. Att kunna ta en storm, Gothenburg: Breakwater, p. 149; b Patriksson, F. 2012, p. 149.

This expansion at the end of the 1980 s was experienced by many as an era of hope. People spoke about the upcoming Golden 9os, where the earnings would be over 100 cents per cubic feet. This discursive construction of the future legitimised the newbuilding programme. Initially, the strategy paid off.

However, there were critical voices. Peter Rothschild, a member of the Five was invited by Bilspedition to evaluate the business operations of Cool 
Carriers in 1987 . Mats Ruhne was involved in producing the report ${ }^{12}$. Some people within the company chose not to cooperate in this evaluation due to the history of the Five, while others did. Although Bilspedition was now the sole owner, the organization was still split and due to the turmoil people had different loyalties. The report criticized the business for having moved away from Cool Carriers' original goal, namely to be a software company. While the upper management of Cool Carriers considered the acquisition of ships a necessity, the report shows that there were dissenting views amongst those still loyal to the Five.

1990 was a really bad year for shipping. Iraq had just invaded Kuwait, and the shipping markets were affected. Bilspedition, which now had investments in reefers, forest product carriers, and oil-bulk-ore vessels, worsened every year. In 1992, the share-price was down to 20 SEK against a peak of 160 SEK at the end of 1989. Because of this unfortunate development, Martin Lundberg was replaced by the new CEO Håkan Larsson and Bilspedition started to sell off their maritime businesses, for example Cool Carriers. This downturn affected the strategy of Cool Carriers. After having engaged in negotiations with different potential buyers, for example NYK and French Altus, in 1994 Cool Carriers was sold to the Avrista consortium, consisting of Höegh, holding $75 \%$ and Tufton Oceanic, holding $25 \%$. The following year, Bilspedition was bought up by the German logistics company Stinnes and the company was renamed Schenker-втL.

To sum up, under the ownership of Bilspedition, Cool Carriers changed strategy, which paid off until the shipping markets started to fall in the early 1990s. The owners, affected by the bad results in the shipping segments, needed to divest. From the perspective of employees at Cool Carriers, Bilspedition was not a particularly competent owner. Although they had recruited an experienced manager for all of their shipping investments, neither he nor the CEO of Cool Carriers had any specialized knowledge of the reefer industry. This resulted in a lack of a business idea for Cool Carriers, when it became clear that it was difficult to attract tonnage to the Leonina pool. We can only speculate what would have happened if the Five would have remained at the helm of Cool Carriers. At least from their perspective, Cool would have developed differently. Since they all were highly competent and had been running SRS, it is likely that their departure negatively affected the business development of Cool Carriers. At the same time, it might have been impossible for them to run Cool Carriers due to their negative reputation within the company. Particularly 
when the market turned down in the early 199os coupled with the problems that Bilspedition underwent, people at Cool Carriers were frustrated. Some key employees decided to leave the organization to work with a growing competitor, Seatrade.

\section{Höegh and the Others: Broadened Market Presence with Limited} Investments

It is time to get acquainted with the new owner of Cool Carriers. Höegh started out in 1927 as a company owning oil tankers, and later expanded into liner shipping (Java Pacific Line and West Africa Line) ${ }^{13}$. In the 1960s the company diversified into oil-bulk-ore carriers and car carriers. The latter business was developed in a joint venture with the Norwegian ship-owner Ugland in 1970 creating HUAL (Höegh Ugland Auto Liners). In 1973, Höegh contracted the world's first LNG carrier with special tanks and started to develop this business segment. In 1987, Höegh underwent an IPO, which was the trend for many shipping companies in the late 1980s. As a consequence of the Exxon Valdez oil-spill and the resulting Oil Pollution Act, which posed greater financial risk for companies engaged in oil transport, Höegh's ово and tanker related activities were demerged and listed. The Höegh group had been through 12 years of consolidations but it was time to expand. In the context of the history of Höegh as a diversified shipping company, a fair interpretation for why Höegh bought Cool Carriers is because Höegh was interested in further diversification. The diversification would not end until 2000, when Höegh placed all its focus on car carriers and LNG.

In other words, it was not an interest in reefers per se, but rather a will to continue exploring different shipping markets, hedging the cyclical nature of various shipping markets against others, that was Höegh's interest for buying Cool Carriers. Höegh, the chairman of Höegh, stated that Cool Carriers was bought due to its strong market position, and that although the reefer market is weak at present, the deal could pay off in the future ${ }^{14}$. As we know, the future is always unknown, and a weak market can be the perfect time to enter a new business segment. Also, reefer shipping was at the time seen as low risk, industrial shipping, and Höegh's decision was not discussed to a large extent in the Norwegian shipping community. Apart from Höegh's own interest in diversifying, a main driving force behind the deal to acquire Cool Carriers is said to have

13 Bakka, D. Jr. 1997. Höegh: shipping through cycles 1927-1997, Oslo: Leif Höegh \& Co Asa.

14 "Leif Hoegh is looking for more cool deals". TradeWinds 28 January 1994, p. 19. 
been Ted Kalborg of Tufton Oceanic - an investment banker - and the holder of $25 \%$ of the shares of Avrista. Soon, however, Höegh bought Tufton's share in Cool Carriers.

Mats Jansson, who had extensive experience leading shipping companies within dry cargo and oil tanker, was appointed CEO of Cool Carriers in May 1994. The strategy of Cool Carriers, when Jansson entered the company was to reduce market risk and get rid of timechartered tonnage. As we know, vessels were timechartered from 1990 to 1995, and given the downturn of the market, the charter price naturally surpassed current market rates.

The result was negative in the first year of operation, 1994, due to the depressed market and the loss-driving timecharter agreements. As a part of the deal, Bilspedition paid the losses during 1994, but then the results turned black. Due to the positive expectations in 1995 and 1996, Höegh expanded its ownership of vessels. Höegh was, as an owner interested in expanding in the segment, particularly through the acquisition of second-hand tonnage ${ }^{15}$. While they had no specific knowledge about the reefer market, they were willing to invest, and to a large extent trusted the local organization with its leader Mats Jansson. Since Höegh was based in Oslo, there were some discussions about moving Cool Carriers to Norway. But, due to the risk of losing know-how - not all were willing to move to Norway, the organization stayed in Stockholm.

By the end of 1995, Höegh therefore invested in reefer vessels connected to Cool. From the annual report, it is stated that the company's total assets had increased from NOK 3,964 million at the end of 1993 to NOK 5,568 by year-end 1995 , a result that is partly attributable to reefers ${ }^{16}$.

Cool Carriers did well during 1995 and 1996, but Mats Jansson had an idea that the company required a greater market presence and a larger fleet in order to reach economies of scale. The management's plan was to collaborate with other players within the industry. A potential partner was the South African liner company Safmarine, which had been founded in 1946. Following the end of the sanctions against South Africa, Safmarine began to look for new opportunities in the international market. Apart from its liner services with container ships, it expanded into the reefer segment and had a fleet of ships as well as a commercial operation. The idea from Cool Carriers' perspective was to take over both the ships and the human resources of Safmarine. The hardware would provide a welcome boost to Cool Carriers' fleet, while the software, called Universal Reefers, included good relationships to the South African fruit exporters Unifruco and Outspan. These exporters were not only partners to

15 "Leif Hoegh is looking for more cool deals". TradeWinds 28 January 1994, p. 18.

16 Leif Höegh Annual Report 1995. 
TABLE 3 Revenues, operating profit, book value of vessels and investment in vessels for Höegh's share of Cool Carriers 1994-2000. In 1997, figures correspond to Höegh's $50 \%$ share of Cool Carriers after the merger with Safmarine

\begin{tabular}{lccccccc}
\hline Year (NOK million) & 1994 & 1995 & 1996 & 1997 & 1998 & 1999 & 2000 \\
\hline Freight revenues & 711 & 744 & 1074 & 752 & $\begin{array}{l}787(107 \\
\text { MUSD })\end{array}$ & 96 MUSD & 174 MUSD \\
Operating profit & -61 & 6 & 4 & 122 & $\begin{array}{l}44(-8 \\
\text { MUSD })\end{array}$ & -9 MUSD & 4 MUSD \\
Book value (vessels) & 174 & 672 & 1291 & 976 & $\begin{array}{l}829(116 \\
\text { MUSD })\end{array}$ & 154 MUSD $) ~ 137$ MUSD \\
$\begin{array}{l}\text { Investments in } \\
\text { vessels }\end{array}$ & 213 & 566 & 722 & 0 & 0 & 0 & 21 MUSD \\
\end{tabular}

a Leif Höegh Annual Report 1997, p. 57, Leif Höegh Annual Report 1998, p. 45, Leif Höegh Annual Report 1999, p. 44.

Universal Reefers but also owned $50 \%$ of it. The fruit exporters, mostly Outspan, wanted to remain in control of the software side and urged Safmarine to keep its 50\% stake. A South African shipping company was a more preferred partner. However, in September 1997, Safmarine pulled out of its ownership in Universal Reefers to avoid a conflict of interest between Cool Carriers and Universal. Universal Reefers would be run by the fruit exporters Unifruco and Out$\operatorname{span}^{17}$.

Höegh and Safmarine joined forces on the 1st of January 1997 and formed the new company Unicool. It consisted of the Cool Carriers software company and 18 ships owned by Höegh and Safmarine and its assets were valued at over 400 MUSD. The ownership structure of the new company was Safmarine International (50\%), Höegh (49.8\%) and Mats Jansson's company Girestad. The company in Stockholm was now both a significant ship-owner and an operator (see Table 4). The organization, the software, was intact, but Safmarine had exchanged the ownership of their vessels for the ownership in Unicool. When discussing the deal with Mats Jansson, he says that the philosophy was to expand, to get a larger market share without a significantly higher risk. Safmarine's fleet also suited Cool Carriers well.

Another aspect of the expansive but still low-risk strategy was to try to collaborate with companies in new pools. Cool Carriers had a relatively small

17 "Safmarine pulls out of charter". South China Morning Post, 17 September 1997, <http:// www.scmp.com/article/211636/safmarine-pulls-out-charter>. 
Spring Bride

Spring Dream

Summer Breeze

Summer Flower

Summer Meadow

Summer Wind

Crystal Prince

Crystal Pride

Crystal Primadonna

Crystal Privilege

Ivory Dawn

Arctic Universal

Baltic Universal

Lincoln Universal

Tasman Universal

Caribbean Universal

Coral Universal

Erikson Crystal

presence in the handy sized reefer segment. A representative of Cool Carriers said that "for two years [i.e. since 1994] Cool has been searching for a partner, realizing it was too small of a player on its own"18.

The partner was a relative newcomer on the reefer scene - Eastwind - with its base in the Us. With a fleet of about 25 handy sized reefers, the new reefer venture ECo Shipping was a fact. The $\mathrm{E}$ in the name came from Eastwind, and the Co from Cool Carriers. The start of the operations was the same date that Safmarine and Höegh joined forces, 1 January 1997. The company was co-managed from Stockholm and from Eastwind's offices in New York. Glenn Selling was head of the Swedish division, while Toby Moors was head of the American. In TradeWinds, more about the respective strengths is understood:

In Eastwind's case this was ten-years' experience of operating small reefers. For Cool Carriers it was a history of building long-term relationships with customers. ${ }^{19}$

18 "Eastwind and Cool to share management". TradeWinds 15 November 1996, p. 12.

19 "Reefer venture on a rough ride" TradeWinds 23 December 1998, p. 11. 
ECo was strong on fish, kiwi from NZ to Japan, mandarines from Morocco to Russia $^{20}$. But in the long run, ECo Shipping was not sustainable. The smaller ships did not have significant earnings due to the heavy competition from the container lines. Rather, Cool Carriers had to focus on larger ships to achieve economies of scale. In 1998, the management of the pool from Stockholm was discontinued, and all commercial management of the ships was taken care of in New York. Eastwind president John Kousi explained: "Rather than us both focusing on each size it made sense for Cool to concentrate on the larger ships and us to focus on the small ships. It means that together we now cover a broad spectrum and that we can offer customers a complete range of sizes"21. In 1999, Eastwind expanded the Eco shipping pool with outside owners ${ }^{22}$.

Cool Carriers delivered a better result in 1997 and the annual report notes that, "high contract coverage and better contribution from cars on traditional ballast legs, in good cooperation with Höegh Ugland Auto Liners, contributed to the improved result" ${ }^{23}$. So, although the business of Höegh and Cool Carriers seemingly had not much in common, some synergies could be created between the car carrying division and the reefer division of Höegh.

Business kept expanding, and Cool Carriers managed to win a contract with Noboa in September 1997, that led to the possibility of an integrated service minimizing ballast voyages. In the Höegh annual report of 1997, the circular trade that according to Cool Carriers was a subjective point of pride was detailed:

Due to its size and customer base, Cool Carriers can offer competitive logistic solutions. One example is the long term agreement entered into with the Noboa group in September for the transportation of bananas from Ecuador to the us west coast and Japan. The transportation of bananas is combined with Cool Carrier's present agreement with Sunkist for the transportation of citrus fruits from the USA to Japan. Backhaul cargoes from Japan includes secondhand cars to South America and New Zealand and from New Zealand apples and kiwi fruit are loaded for Europe. This is a good example of a system which through a combination of cargoes optimizes the utilization of the vessels, creating a more cost efficient solution for the customers ${ }^{24}$.

\footnotetext{
$20 \quad$ Svensk Sjöfarts Tidning 1996/47, p. 6. Interview Glenn Selling.

21 "Reefer venture on a rough ride" TradeWinds 23 December 1998, p. 11.

22 "Rates prompt reefer players to opt for spot" TradeWinds 18 February 2000.

23 Leif Höegh Annual Report 1997, p. 54

24 Leif Höegh Annual Report 1997, p. 54
} 
Furthermore, a new pool was set up, which was similar to the setup of ECo Shipping. The reason was that "increased competition from the container lines - and customer demands for fixed arrivals, reefer containers, and special quality requirements - has locked much of the more sophisticated reefer tonnage into fairly rigid trading systems. This change in the main market has left a large fleet of less sophisticated, standard pallet-reefer vessels of good quality outside the systems. However, these vessels still offer competitive advantages and flexibility to many customers, owing to cost advantages". It was further explained that:

The company will focus on traditional reefer shipping but will also engage in emerging markets with future potential, and specialise in the somewhat shorter market perspective allowing it to take advantage of opportunities arising from short to medium term market fluctuations ${ }^{25}$.

On 1 January 1999, Arctic Reefers was set up with tonnage from Ahrenkiel of Hamburg, Eastwind of New York, Mediteranska Plovidba of Korcula, the Dawn group of London, Tokumaru Kaiun of Tokyo, Zodiac of London and Osterreichischer Lloyd of Vienna.

Also, the creation of Arctic Reefers was a result of the Cool Way - a new strategy announced in 1998. They thought of this as the Toyota Way of reefer shipping, with a base in skilled and competent staff, customized services, enhanced operative efficiency, and cutting-edge technology. This is also a discursive strategy to position oneself as a well-organized and modern company. For example, a new liner service to South Africa offered door-to-door services when the export market was deregulated in 1999. The Cool Way was seen as the core of Cool Carriers, and the creation of Arctic Reefers was also a way to distance Cool Carriers from its less sophisticated, but still potentially profitable, tonnage.

On the tonnage side of the business, two newbuildings were made. In 1996, Mediteranska Plovidba, or Medplov, of Croatia ordered two 600 ooo cbf reefer vessels at Split Shipyard, with a scheduled delivery for the end of 1998 and early 1999, for an estimated 30 mUSD each. Mediteranska Plovidba, a state-owned shipping company, had close relationships with the Split shipyard and it is plausible that ships were ordered to secure employment at the shipyard. Since the early 1980s Medplov had ordered seven reefer ships at Split, many of which have been operated by Cool Carriers ${ }^{26}$. Höegh took an ownership share in the

$25 \quad$ Leif Höegh Annual Report 1998.

26 "Split clinches double-reefer order" TradeWinds 29 November 1996, p. 5. 
two ships, of $20 \%$ each. The first one was delivered in January $2000^{27}$. According to Cool Carriers, these ships were probably the last ones needed of today's reefer design. However, the staff at Cool Carriers were working on the next generation of reefer vessels, called the Pallcon vessels, in which loading and unloading of the fruit pallets would take place utilizing elevators through side doors in the hull. Also, a high container capacity was a main part of the design.

Turning to ownership, according to the upper management, the relationship between Safmarine and Höegh went remarkably well. This dual ownership also led to more independence and agency for the Cool Carriers organization to develop its own strategy. Of course, the strategy had to benefit the owners, but both owners adopted a hands-off policy and let the competent staff led by Mats Jansson run the show. But it seemed that Cool Carriers was destined to be plagued by ownership problems.

The owner of Safmarine, the insurance company Old Mutual, was going to do an IPO in 1999 and wanted to sell their shipping interests before the IPO. Maersk bought the liner business of Safmarine ${ }^{28}$, and the bulk and reefer divisions were sold to Capital Finance (owned by the Greek family Restis) for R210 million, or about $35 \mathrm{~m} \mathrm{USD}{ }^{29}$. Restis and their related company Enterprise Shipping and Trading was established in 1973 and consisted at that time of one reefer ship. In 1995, they had built up a managed fleet of 26 reefers. But the main objective for Restis when buying Safmarine, was not its reefers, but its bulkers ${ }^{30}$. When Restis bought Safmarine's share of Unicool, Guttormsen from Höegh stated:

We are very happy about this and know Restis already, as the company has had vessels in the Cool Carriers pool before. It is a long term player in this market and that is also positive ${ }^{31}$.

TradeWinds reported that Höegh had not been consulted before Safmarine sold its stake to Restis. And behind the happy facade, there was a concern that Restis was not a suitable owner for Cool.

The collaboration between Restis and Höegh was far from harmonious. We have stated that Höegh ran Cool Carriers as a stand-alone operation, while

27 "Hoegh takes stakes in two reefers" TradeWinds 8 April 2000.

28 Jephson, C. and Morgen, H. 2014. Creating Global Opportunities, Maersk Line in Containerisation 1973-2013, Cambridge: Cambridge University Press, p. 263.

29 "South Africa: Safmarine Falls Into Foreign Hands". AllAfrica 8 April 1999, <http://allafri ca.com/stories/199904080036.html>.

$30 \quad$ "Restis gains a stake in reefers" TradeWinds 9 April 1999.

$31 \quad$ "Restis gains a stake in reefers" TradeWinds 9 April 1999. 
Restis had a much more hands-on approach. From the perspective of the former's locus of agency, Cool Carriers' upper management, there were a range of issues that hindered a harmonious collaboration. At first, Restis wanted to integrate his own reefers into the Cool Carriers operation, old reefers that did not fit into the high-quality profile of Cool Carriers ${ }^{32}$. This was met with scepticism from Cool Carriers since it diluted the brand and complicated the operations. Also, compared to Safmarine and Höegh, Restis was not interested in developing Unicool and continuing the expansion, but wanted to commit their funds to other segments, such as bulk. Restis also questioned why Cool Carriers had so much cash. Cool Carriers' personnel speculated that Restis was probably more interested in the hardware part of Unicool rather than in the software. Cool Carriers, the former locus of agency, had now a rival who saw the software as an obstacle rather than a resource. We know, however, that Cool Carriers has always been an independent organization willing to oppose owners that they did not like. And this is exactly what happened - there was resistance. If Restis would have owned $100 \%$ of the company, such resistance would have been futile, but it is likely that Cool Carriers, together with Höegh, collaborated to reach a solution.

It was decided that to solve the deadlock, which hampered business development, one party had to buy out the other. There was a so-called Texas Close Up, where you placed a bid for either selling or buying the ships. If your bid was 100 it meant that you either had to buy the vessels for 100 or sell the vessels for 100. The highest bidder wins. Restis won the Texas Close Up, but after some turbulence, Höegh became $100 \%$ owner of Cool Carriers from the beginning of 2000.

Höegh had been an appreciated owner, but as the 200os were approaching, Höegh believed that the reefer segment did not have a viable future. Furthermore, the financial resources tied up in the reefer business could be better used in the car carrying and LNG segments. Höegh was looking for an exit.

This exit affected the business development of Cool Carriers. In fact, there was a newbuilding program underway at Cool Carriers with the Israeli company Agrexco (Agricultural Export Company), a leading exporter of Israel's fruit. Agrexco were using two ships for their exports, but both of them were built in the early 1970s and needed replacement, not the least due to their low container capacity ${ }^{33}$. The two newbuildings that Cool Carriers were developing were far from ordinary. They had pallet friendly reefer holds, and tween-

32 "Cool couple splits up" TradeWinds 26 November 1999.

33 The container capacity was 80 TEU. "New Reefer up Agrexco fruit trade" TradeWinds 24 October 2003, p. 16. 
decks with side doors. Also, they had a box capacity of 880 TEU. They were described as "part reefer, part container and part roll-on, roll-off and have side loaders"34. In other words, completely customized ships for a particular company's transport needs. But due to the exit of Höegh, the owner was far from willing to commit to take part-ownership in the vessels. The negotiations were stalled to great frustration for Cool Carriers staff, and eventually the ships were ordered by another owner. Delivered in 2003, they turned out to be very bunker inefficient and heavy ships. This did not matter that much since they were tailormade for Agrexco, but when Agrexco went into bankruptcy in 2011, the upper management of Cool Carriers were relieved that they did not carry out the project.

Höegh was looking to exit and Lauritzen turned out to be the buyer. We will describe this deal more in the part on Lauritzen's history. Höegh exited the software part in 2001, but retained ownership in the vessels, since Lauritzen was only interested in the software and not in the hardware. From 2000, Höegh dismantled its reefer fleet, and finalized their exit by 2003 (See Table 5).

TABLE 5 Höegh's exit from the reefer segment

\begin{tabular}{lllll}
\hline Year $^{\mathrm{a}}$ & 2000 & 2001 & 2002 & 2003 \\
\hline Reefers & 17 & 14 & 12 & 0 \\
\hline
\end{tabular}

a Höegh Annual Report 2000, 2001, 2002, 2003.

\section{Summary}

Cool Carriers started out as a continuation of the reefer division that existed at Saléns. Given the foresight and risk awareness of the upper management of the reefer division, Cool Carriers could be set up immediately after the bankruptcy. Much of the identity of the former organization was carried on to Cool Carriers. In the post-bankruptcy disorder, it was not entirely clear how everything was organized regarding ownership of both the organization and the related ships and this led to shattered expectations, broken promises, and harsh conflicts between the organization and the upper management of Cool Carriers

34 "Breakbulk carrier Seatrade orders container ships". Journal of Commerce, 2 August 2014, $<$ http://www.joc.com/maritime-news/container-lines/breakbulk-carrier-seatrade-or ders-container-ships_20140802.html>. 
- the Five - as well as within the owner consortium. Given the antagonism between the rest of Cool Carriers and the upper management and owners, the organization developed a subjective sense of autonomy which is complemented with a discourse that they are in control - that "they have to look for other owners" if the present owners do not suit their taste. This new subjective dimension was an addition to Salén Reefer's subjective feeling of market-leading knowledge, operational excellence and working with high-class customers which also continued to reign at Cool Carriers. During the late 1980s the market prospects looked good and people discursively described the 1990s as being "golden". However, the 1990s never fully lived up to these expectations. Throughout that decade, Cool Carriers had different owners but still they perceived themselves to be in charge, and also resisted when the owners acted too much against their interests. This subjective feeling of pride and autonomy thus significantly affected the business of Cool Carriers. The main organization - Cool Carriers - was discursively positioned as modern and high-class with large reefers, even though they also owned second-tier brands such as ECo and Arctic, which were separated from the main organization, but still linked to it. Now, in 2001, Cool Carriers had been acquired by Lauritzen, and when you read the story about Lauritzen from the mid-1980s onwards to the acquisition, please note the interesting similarities and differences that existed, in terms of fleet renewal and profitability, discursive positioning, and subjective feelings. 